Allluo 993075

NAT'L INST OF STANDARDS \& TECH R.I.C.

IN| |.

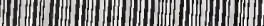

A11100993075

Kelly, George E/Dynamlc performance of

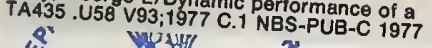

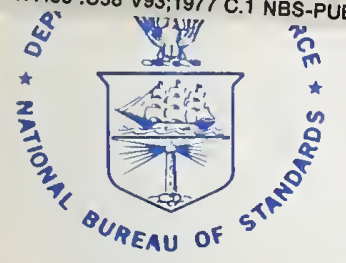

NBS BUILDING SCIENCE SERIES 93

\title{
U.S. DEPARTMENT OF COMMERCE/ National Bureau of Standards
}

\section{Dynamic Performance of a Residential Air-to-Air Heat Pump}
$\mathrm{TA}$
435
.458
No.93
1977
c.2 


\section{The Building Science Series}

The Building Science Series disseminates technical information developed at the National Bureau of Standards on building materials, components, systems, and whole structures. The Series presents research results, test methods. and performance criteria related to the structural and environmental functions and the durability and safety characteristics of building elements and systems.

These publications, similar in style and content to the NBS Building Materials and Structures Reports (1938-59), are directed toward the manufacturing, design, construction, and research segments of the building industry, standards organizations, and officials responsible for building codes.

The material for this Series originates principally in the Center for Building Technology of the NBS Institute for Applied Technology. The publications are divided into three general groups: Building Systems and Processes; Health, Safety and Comfort; and Structures and Materials. For further information regarding these publications please contact the Program Planning and Liaison Unit, Center for Building Technology, Institute for Applied Technology, National Bureau of Standards, Washington, D.C. 20234. 


\section{Dynamic Performance of a Residential Air-to-Air Heat Pump}

George E. Kelly and John Bean

Center for Building Technology

Institute for Applied Technology

National Bureau of Standards

Washington, D.C. 20234

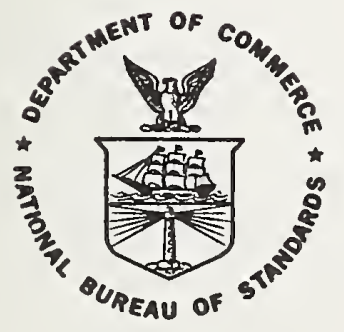

U.S. DEPARTMENT OF COMMERCE, Juanita M. Kreps, Secretary

Dr. Betsy Ancker-Johnson, Assistant Secretary for Science and Technology NATIONAL BUREAU OF STANDARDS, Ernest Ambler, Acting Director

Issued March 1977 
Library of Congress Cataloging in Publication Data

Kelly, George E., 1944-

Dynamic performance of a residential air-to-air heat pump.

(National Bureau of Standards Building Science Series; 93)

Supt. of Docs. no.: C13.29/2:93

1. Heat pumps-Testing. I. Bean, John, joint

author. II. Title. Ill. Series: United States. National Bureau of Standards. Building Science Series; 93. TA435.U58 no. 93 [TH7638] $690^{\prime} .02$ Is [621.4'025] 76-50050.

\section{National Bureau of Standards Building Science Series 93}

Nat. Bur. Stand. (U.S.), Bldg. Sci. Ser. 93,18 pages (Mar. 1977)

CODEN: BSSNBV

\section{U.S. GOVERNMENT PRINTING OFFICE}

WASHINGTON: 1977

For sale by the Superintendent of Documents, U.S. Government Printing Office

Washington, D.C. 20402 - Price 45 cents

Stock No. 003-003-0169l-8

There is a minimum charge of $\$ 1.00$ for each mail order 


\section{Contents}

1. Introduction

2. Experimental Equipment

3. Experimental Procedure

4. Experimental Results _ 6

5. Comparison With Present Present day Fossil-Fuel Heating Equipment _-_-_-_-_-_-- 10

6. Discussion -

7. References 


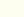




\title{
Dynamic Performance of a Residential air-to-air Heat Pump*
}

\author{
George E. Kelly \\ Mechanical Systems Section \\ and \\ John Bean \\ Thermal Engineering Section \\ Center for Building Technology \\ National Bureau of Standards \\ Washington, D.C. 20234
}

\begin{abstract}
Information is presented on the dynamic performance of a 5-ton air-to-air heat pump, which was installed in a residence in the Washington. D.C. area. The effect of part-load operation on the heat pump`s COOLING and HEATING coefficients of performance (COP) was determined. When the pump operated in the heating mode at outdoor temperatures below $10^{\circ} \mathrm{F}\left(4.4^{\circ} \mathrm{C}\right)$, a considerable discrepancy was found to exist between the measured performance and the performance data supplied by the manufacturers. This discrepancy is apparently due to the adverse effects of frost buildup and defrosting of the outdoor coil. The seasonal performance factor (SPF) of the heat pump was estimated and then traced back to the power plant to obtain an "EFFECTIVE SPF" which is then compared with the performance which might be expected from fossil-fuel heating equipment.
\end{abstract}

Key words: Cooling and heating coefficients of performance; effective heating COP; heat pumps; heat pumps and energy conservation: part-load performance; seasonal performance factor.

\section{Introduction}

With approximately 11 percent of the total energy consumed in the United States [1] $]^{1}$ going into the space heating of residences, there is an urgent need for information on the energy effectiveness of the various systems used for residential heating. These systems include the traditional fossil-fuel heating equipment, such as gas-or-oil fired furnaces and boilers, electrical resistance heating systems, such as electric furnaces and baseboard units, and air-toair heat pumps. Unfortunately, at the present time there exists very little published data on the partload and seasonal performance of either the fossilfuel or air-to-air heat pump systems.

In an attempt to obtain quantitative information on the dynamic performance of air-to-air heat pumps, a 5-ton heat pump was installed in a 20year-old house (known as the Bowman house) in the Washington, D.C. area. This heat pump experiment was part of a larger program to experimentally measure the energy savings which could be achieved through retrofitting. The approach used consists of measuring the heating and cooling requirement of an old home and then making various energy saving modifications [2]. By measuring the energy requirements of the house after each

-This research was sponsored by the Federal Energy Administration.

1 Figures in brackets indicate the literature reterences at the end of this paper. modification, an estimate of the energy savings resulting from each change could be made. The house studied was a single-story frame ranch-type residence which was built in the early $1950^{\circ} \mathrm{s}$ and had a floor area of approximately $2500 \mathrm{sq} f t(232.25$ $\mathrm{m}^{2}$ ).

The Bowman house was originally heated by an oil-fired, warm-air furnace and this furnace was used in determining the pre-retrofit heating requirement of the house during the 1973-74 winter period. The furnace was removed in the spring of 1974 and a heat pump installed in its place. with little modification made to the existing duct system. The heat pump was instrumented and used to measure the pre-retrofit cooling requirement of the house during a test period in the summer of " 74 .

During the 1974-75 winter, various modifications were made to the house to reduce the energy needed for heating and cooling purposes. First, weather stripping and caulking were applied around the doors and windows. after which the heating requirement of the house was determined. The next stage of retrofitting consisted of installing storm windows and then remeasuring the heating requirement of the house. The third and last stage of the post-retrofit heating test consisted of adding additional insulation to the 4 inches already existing in the attic, blowing insulation into the walls. and then measuring the new heating requirement of the house. The post-retrofit cooling requirement of the house was measured during the summer of 1975 . 
The data presented in this paper pertain to measurenients of the heat pump's performance made during the pre-retrofit cooling test, the first stage of the post-retrofit heating test (after caulking and weather stripping) and after the second stage of the post-retrofit heating test (after the installation of storm windows). The performance of the air-to-air heat pump after the placement of additional insulation in the attic and the blowing of insulation into the walls will not be discussed, since this modification resulted in a greatly oversized heat pump with different performance characteristics. The pre-retrofit cooling test lasted for a period of four days. and 373 hours of heating data were obtained for the combined first and second stages of the post-retrofit heating test.

\section{Experimental Equipment}

The 5-ton heat pump installed in the Bowman house was a commercially available, split system employing thermostatic expansion valves. It was sized to meet the calculated pre-retrofit cooling requirements of the house, which was determined using ASHRAE procedures [3]. Figure 1 is a schematio of the indoor section, which contained the indoor coil. indoor blower, supplemental resistance heaters, and the expransion valve employed when the heat pump was used to cool the house. The outdoor section, shown in figure 2, contained the outdoor coil. outdoor fan, compressor, accumulator, switchover valve, and the expansion valve used during the heating process.

The heating duct system is shown schematically in figure 3. Half the house was over a basement and the wher half over a crawl space, and there were separate supply and return ducts for each half of the house. The return air was fed into a return air plenum and then into the indoor air handler, where it was either heated or conted. Upon leaving the indoor air handler, the air entered the two supply ducts, where air-flow monitoring devices were used to measure the mass flow rate of air delivered to each half of the house. Each of these air-flow monitoring devices was purchased commercially and consisted of honeycomb straighteners and a rake of Pitot tubes located at centers of equal area. By measuring the difference between the average total and the average static pressure in each supply duct and knowing the barometric pressure and the temperature of air in each duct, the mass flow rate of air delivered to each half of the house could be ralculated. Two 36-junction copper-constantan themopiles, which were located as shown in figure 3 , were lised to measure the temperature rise or drop in the air delivered to each supply duct as it passed through the air handler. The output of each thermopile was fed into an electronic integrator, which allowed for calculation of the average temperature difference between the return plenum and each supply duct over a period of time. The main supply ducts, as well as the branches leading to the individual room registers,

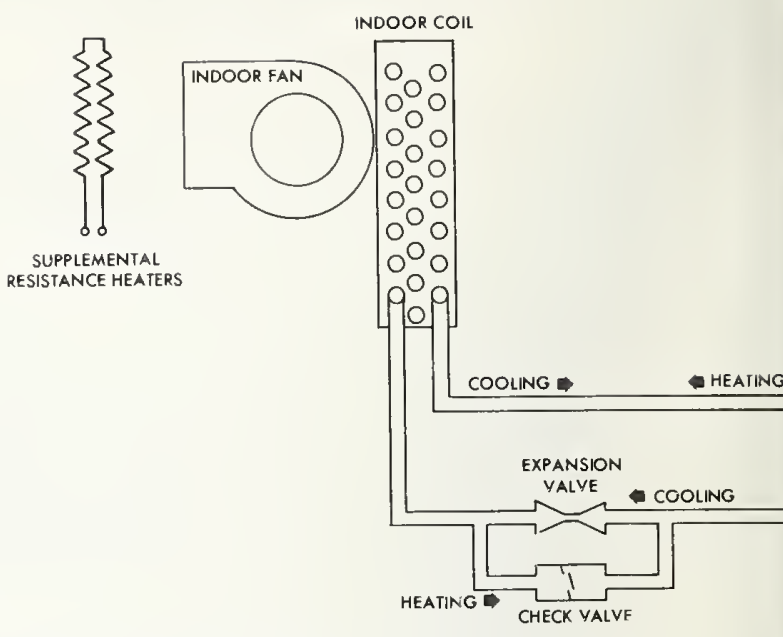

FIGURE 1. Schematic of heat pump's indoor unit.

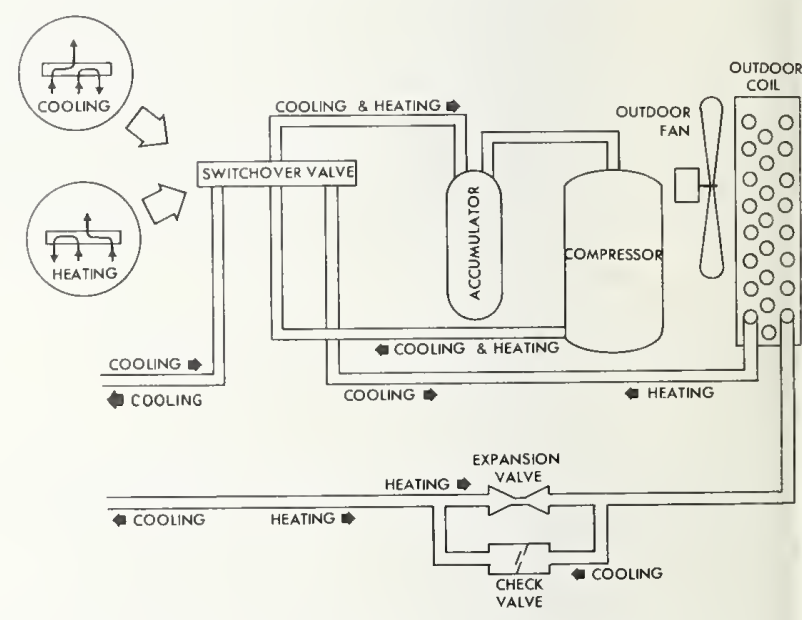

FIGL RE 2. Schematic of heat pump's outdoor unit.

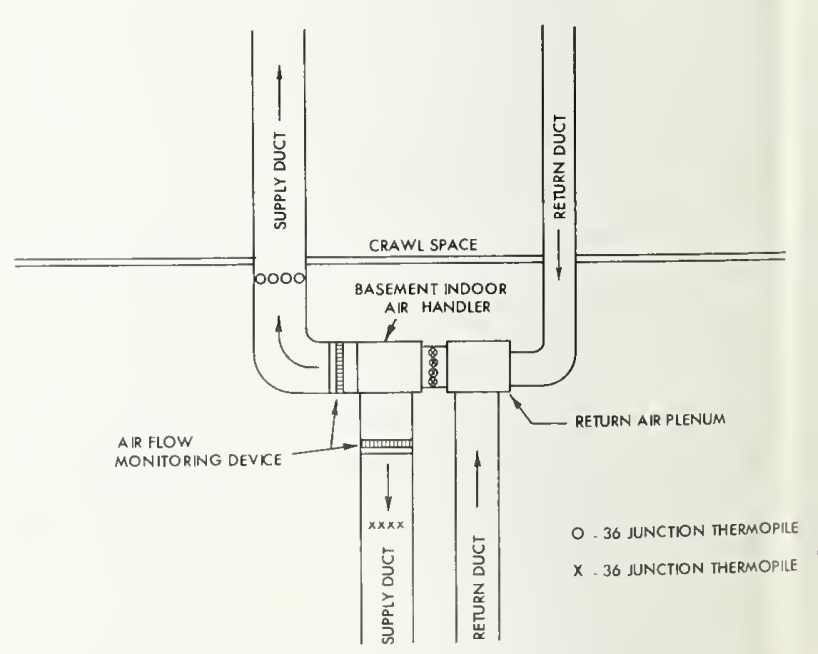

FIG, RE 3. Schematic of duct srstem in the Bouman house. 
were insulated in order to cut down the heat losses from these ducts.

During the summer cooling test, the condensate produced by the indoor coil was collected in a large container which was located on top of a mechanical scale. By weighing the condensate hourly the latent cooling done by the heat pump was determined. The relative humidity sensor in the return air plenum was used to compare the measured cooling performance of the heat pump with that predicted in the manufacturer's specifications.

Watt-hour meters were used to measure the energy input to the compressor, outdoor fan and the indoor blower and, during the winter test, to the supplemental resistance heaters. Although the watthour meters used during the cooling test had to be read manually, the ones employed on the heating test were equipped with an internal set of contacts. A pulse counter-printer was used to count the number of contact closures. A signal from an external source would cause the pulse counterprinter to print out and then reset to zero.

Strip-chart recorders and copper-constantan thermocouples were used to continuously record the air temperature in the return air plenum and in both supply ducts. These recordings allowed for constant monitoring of the heat pump and provided information on the length of ON-time and OFF-time. In addition, the return-air temperature measurement was necessary in order to accurately compare the measured heating and cooling performance of the heat pump with the manufacturer's performance data.

The oufdoor temperature and relative humidity were also recorded hourly. The copper-constantan thermocouple and relative humidity $(\mathrm{RH})$ sensors, used to measure the outdoor temperature and the humidity were housed in a small outdoor instrument shelter.

\section{Experimental Procedure}

In both the cooling and heating modes of operation, the performance of the heat pump is described by its coefficient of performance or COP. When the heat pump is used to cool the house, the coefficient of performance, which in this case may be referred to as the COOLING COP, is the ratio of the total heat extracted from the return air to the total energy supplied to the heat pump. When the heat pump is used for heating, its coefficient of performance or HEATING COP is the ratio of the total heat delivered by the heat pump system to the total energy input to the system. In this paper, the heat pump system is defined to include the input and output of the first step of the supplemental resistance heaters when this step operates during a defrost period. During periods of operation not involving defrost, the input and output to the supplemental heaters are not included in the calculations to determine the HEATING COP. This definition of the heat pump system was adopted because it was felt that the heat pump should be penalized for the energy required to temper the supply air during the periods that heat is being extracted from the return air in order to defrost the outside coil. During defrost, the first stage of supplemental resistance heaters in the Bowman house installation was capable of just canceling the cooling effect of the indoor coil, which resulted in a supply air temperature approximately equal to the return air temperature and neither heating or cooling being done to the interior space.

When the heat pump cools the interior space, the total cooling, $Q^{c}(\tau)$, done over a time period $\tau$ is given by the equation [1]

$$
Q^{c}(\tau)=Q_{s}^{c}(\tau)+Q_{L}^{c}(\tau)
$$

where $Q_{s}^{c}(\tau)$ is the total sensible cooling and $Q_{L}^{c}(\tau)$ is the total latent cooling done during the time period $\tau$. The quantities $Q_{s}^{c}(\tau)$ and $Q_{L}^{C}(\tau)$, in addition to depending on the time period $\tau$, depend upon the outdoor dry-bulb temperature, the indoor wetand dry-bulb temperatures, the rate of air flow through the indoor unit, the performance of the heat pump's various components, and the cooling load of the house.

The quantity $Q_{s}^{c}(\tau)$ is determined using:

$$
Q_{s}^{c}(\tau)=\overline{C_{p}} \sum_{i=1}^{2} \overline{\dot{m}_{i}} \overline{\Delta T_{i}(\tau)}
$$

where $\overline{C_{p}}$. is the average specific heat of the airwater mixture leaving the indoor unit for typical ON-cycle conditions,

$i=1,2$ pertains to the supply ducts passing through the basement and crawl space,

$\overline{\dot{m}}_{i} \quad$ is the average mass flow rate of the airwater mixture in supply duct $i$ during $\mathrm{ON}$ periods.

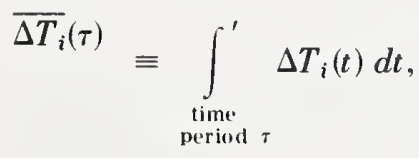

$\int^{\prime} \quad$ in the equation defining $\overline{\Delta T}_{i}(\tau)$ indicates that integration is to be carried out during periods when the heat pump is operating.

$\Delta T_{i}(\tau)$ is the absolute value of the change in drybulb temperature experienced by the air entering supply duct $i$ at time $\tau$ as it passes through the indoor unit.

It has been assumed that there is no cooling of the interior living space during the OFF-cycles. since the indoor blower and heat pump ceased operating at the same time and the location of the indoor unit in the basement prevented any natural convective cooling. 
During each of the four days in the pre-retrofit cooling test, the mass flow rate in each supply duct was periodically measured while the heat pump was on. These values were then averaged to find an average air flow rate, $\dot{\dot{m}}$, for each supply duct which was used in eq (2) to determine the sensible cooling provided by the heat pump. The standard deviations of these measured mass flow rates were approximately 2 percent and 3 percent of the average mass flow rates for the two supply ducts. The quantities $\Delta T_{i}$ were measured with thermopiles and then integrated over time using electronic integrators. During the OFF-periods, the signals to the integrators were shorted, which effectively set $(\Delta T)_{i}$ equal to zero and this was equivalent to integrating only over the ON-periods.

The total latent cooling provided by the heat pump over a time period $\tau$ was determined using the equation:

$$
Q_{L}^{c}(\tau)=\Delta W(\tau)\left(h_{g}(T)-h_{f}(T)\right)
$$

where $\Delta W(\tau)$ is the weight of condensate collected in this time period, and $h_{g}(T)$ and $h_{f}(T)$ are the specific enthalpies of saturated water vapor and saturated liquid, respectively, at the average evaporator coil temperature $T$.

The COOLING COP was calculated using:

$$
\text { COOLING COP }=\frac{Q^{c}(\tau)}{I(\tau)}
$$

where $I(\tau)$ is the total measured energy input to the heat pump during the period of time, $\tau$, used to determine $Q^{c}(\tau)$. For evaluating the COOLING $\mathrm{COP}$, data were collected hourly on $\overline{\Delta T}, \Delta W$ and $I$ and these hourly values were then combined to obtain values for time periods $\tau$, which either contained an integral number of complete $\mathrm{ON}-\mathrm{OFF}$ cycles or consisted of all the consecutive hours in a 24-hour period for which a cooling load existed.

Two cooling tests were also run with the heat pump operating in a steady-state manner. One test was for a three-hour period and the other was for a one-hour period. In order to achieve approximately steady indoor conditions, the doors and some of the windows in the house were partially opened and the heat pump allowed to operate until conditions stabilized. Data were then collected hourly on $\overline{\Delta T_{i}}, \Delta W$, and $I$, and the steady-state COOLING COP was calculated for each of the four one-hour periods.

When the heat pump operated in the heating mode, the total heat $Q^{H}(\tau)$, delivered to the interior living space during the time period $\tau$, is given by:

$$
Q^{H}(\tau)=\sum_{i=1}^{2} \int_{\substack{\text { time } \\ \text { period } \tau}} C_{p i}(t) m_{i}(t) \Delta T_{i}(t) d t \simeq
$$

$$
\begin{aligned}
& \simeq \overline{C_{p}} \sum_{i=1}^{2} \overline{m_{i}} \overline{\Delta T_{i}(\tau)} \\
& \quad+\left\langle C_{p}\right\rangle \sum_{\substack { i=1 \\
\begin{subarray}{c}{\text { off } \\
\text { period } \\
\text { in } \tau{ i = 1 \\
\begin{subarray} { c } { \text { off } \\
\text { period } \\
\text { in } \tau } }\end{subarray}} m_{i}(t) \Delta T_{i}(t) d t
\end{aligned}
$$

where $C_{p i}(t)$ and $\dot{m}_{i}(t)$ are the specific heat and mass flow rate at time $t$ of the air-water mixture entering supply duct $i, \overline{C_{p}}, \overline{\dot{m}}_{i}, \overline{\Delta T_{i}(\tau)}$ and $\Delta T_{i}(t)$ are the same as defined for equation 2 , and $\left\langle C_{p}\right\rangle$ is the specific heat of the air-water mixture leaving the indoor unit for typical OFF-cycle conditions. The average mass flow rate during ON-periods, $\dot{m}_{i}$, was determined by periodicall $y$ checking the mass flow rate in supply duct $i$ throughout the heating test. The standard deviations of the measured mass flow rates were approximately 1.6 percent and 1.1 percent of the average mass flow rates for the two supply ducts. The quantities $\overline{\Delta T_{1}(\tau)}$ and $\overline{\Delta T_{2}(\tau)}$ were determined in the same manner as for the cooling test, with the signals to the integrators being shorted during OFF-periods. The convective heating, which corresponds to the second term on the right-hand side of eq (5b), was estimated by running a series of tests to measure the change with time in $\dot{m}_{i}(t)$ and $\Delta T_{i}(t)$ after the heat pump shut off. The mass flow rate was measured at various cross sectional positions in each supply duct using a hot-wire anemometer, and $\Delta T_{i}(t)$ was obtained using the two 36-junction thermopiles and strip-chart recorders. It was found that the convective heating term could be approximated in this series of tests by an equation whose independent variable was the length of the OFFperiod, provided that the OFF-period was less than 30 minutes. When the OFF-period exceeded 30 minutes, a constant value was used. This approximation was then used to estimate the convective heating provided during OFF-periods throughout the entire post-retrofit heating tests, since it was impractical to measure this quantity for each individual cycle. Although the use of one approximation for all $\mathrm{OFF}$-periods could introduce a small error, the effect of this error on the heating COP was small since the convective heating term was a small percentage of the total heat term, $Q^{H}(\tau)$.

In the post-retrofit heating test, the quantities $\overline{\Delta T_{1}(\tau)}$ and $\overline{\Delta T_{2}(\tau)}$, and the energy inputs to the indoor blower $\left(I_{B}\right)$, the outdoor fan and the compressor $\left(I_{0}\right)$, and supplemental resistance heaters $\left(I_{R}\right)$, were obtained for each ON-OFF cycle. This was achieved by having the pulse counter-printer, attached to the watt-hr meters, and the two integrators, used to integrate the signals from the thermopiles, print out and reset to zero each time the heat pump came on. The total heat delivered during each $\mathrm{ON}-\mathrm{OFF}$ cycle was then computed and used to calculate the HEATING COP for each cycle using the equation: 


$$
\text { HEATING COP }=\frac{Q^{\prime \prime}\left(\tau_{1}\right)}{I^{\prime}\left(\tau_{1}\right)}
$$

where $\tau_{1}$ is length of the ON-OFF cycle and

$$
I^{\prime} \equiv\left\{\begin{array}{l}
I_{B}+I_{0} \text { when no defrosting takes place } \\
\text { during the ON-OFF cycle } \\
I_{B}+I_{0}+I_{R 1} \text { when a defrost process } \\
\text { occurs during the ON-cycle. }
\end{array}\right.
$$

The quantity $I_{R 1}$ is the energy input to the first step of supplemental resistance heaters and is equal to $I_{R}, I_{R} / 2$ or $I_{R} / 3$, depending on whether one, two or three steps of resistance heaters were operating during the defrosting process.

Four steady-state tests were also performed to measure the COP of the Bowman house heat pump when it was operating continuously in the heating mode. Two of the tests were done when the outdoor temperature was above $50^{\circ} \mathrm{F}\left(10^{\circ} \mathrm{C}\right)$ and they consisted of operating the heat pump for approximately a half hour until steady-state conditions were reached and then measuring the energy input and heat output over a half-hour test period. The same procedure was followed in the other two steady-state tests, except that since they were performed at lower outdoor temperatures the heat pump was first made to go through a defrost cycle. This removed any frost which may have accumulated on the outdoor coil and resulted in a measured COP which represented the maximum performance achievable by the heat pump at the given indoor and outdoor test conditions. As in the steady-state cooling tests, the doors and windows in the Bowman house were partially opened in order to achieve the approximately steady indoor conditions necessary for the performance of these four tests.

During the pre-retrofit cooling test, the postretrofit heating test and the steady-state heating and cooling tests, a considerable number of additional measurements were made. These measurements included hourly readings of the outdoor drybulb temperature and continuous strip-chart recordings of the dry-bulb temperature and relative humidity of the return air as it entered the indoor unit. These latter measurements were used to obtain the average outdoor dry-bulb and the average indoor dry-bulb and wet-bulb temperatures existing during periods for which COOLING AND HEATING COP's were calculated. These average indoor and outdoor conditions were then used in conjunction with the manufacturer's performance data to obtain the cooling and heating COP's which the manufacturer claimed the heat pump should achieve under these conditions, if it had been operated in a steady-state manner. By dividing the measured COOLING or HEATING COP by the manufacturer's respective steady-state cooling or heating COP at the same indoor and outdoor conditions, an indication of the effect of part-load operation on the heat pump's performance was obtained.

The air flow rates encountered in the Bowman house during the cooling and heating tests were slightly less than the $2,000 \mathrm{CFM}\left(56.65 \mathrm{~m}^{3} / \mathrm{min}\right)$ for which the manufacturer's performance data were available. The average air flow rate during the cooling test was approximately 1750 CFM $(49.56$ $\mathrm{m}^{3} / \mathrm{min}$ ), and correction factors supplied by the manufacturer were used to calculate the steadystate capacity and compressor power consumption. The average air flow rate during the post-retrofit heating tests was around $1680 \mathrm{CFM}\left(47.58 \mathrm{~m}^{3} / \mathrm{min}\right)$ and the corresponding correction factors employed in obtaining the steady-state COP from the manufacturer's performance data were obtained by a small extrapolation of the correction factors supplied by the manufacturer. From these correction factors, it was found that the reduction in air flow rate from $2000 \mathrm{CFM}\left(49.56 \mathrm{~m}^{3} / \mathrm{min}\right)$ to around 1680 CFM (47.58) during the post-retrofit heatinv test resulted in an approximate 6 percent decrease in the HEATING COP of the heat pump. The values presented in sections 4 and 5 for seasonal HEATING COP, EFFECTIVE HEATING COP, SPF and EFFECTIVE SPF may thus be approximately corrected to an air flow rate of 2000 SCFM $\left(49.56 \mathrm{~m}^{3 /}\right.$ min) by multiplying them by 1.06 .

Since there is no perfect correlation between the hourly cooling or heating requirement of a house and the difference between the indoor and outdoor dry-bulb temperatures, it was necessary to determine the actual cooling and heating load factors in order to properly evaluate the dynamic performance of the heat pump under test. The equations used to define these load factors were:

\section{COOLING \\ LOAD \\ FACTOR

$$
\begin{aligned}
& \text { COOLING DONE BY THE } \\
& =\frac{\text { HEAT PUMP IN TIME } \tau}{\text { (MANUFACTURER'S }}
\end{aligned}
$$

HEATING DONE BY THE

$\begin{aligned} & \text { HEATING } \\ & \text { LOAD } \\ & \text { FACTOR }\end{aligned}=\frac{\begin{array}{c}\text { HEAT PUMP SYSTEM IN } \\ \text { TIME } \tau\end{array}}{\begin{array}{c}\text { STEADY-STATE HEAT- } \\ \text { ING CAPACITY) }(\tau)\end{array}}$

where $\tau$ is a time period or cycle over which the cooling or heating COP was measured and it is to be understood that the manufacturer's steady-state cooling or heating capacities correspond to the average indoor and outdoor conditions which existed in the time period $\tau$. The numerator in eq (7b) includes the output from the first step of supplemental resistance heaters when this step operated during a defrost period to offset the cooling effect of the indoor coil during this period. 


\section{Experimental Results}

The effect of part-load operation on the cooling performance of the Bowman house heat pump is shown in figure 4 . The ordinate in this figure is the ratio of the measured COOLING COP to the COOLING COP calculated from the manufacturer's steady-state performance data for the average indoor and outdoor conditions existing during the measurement period. The abscissa is the cooling load factor which was defined in eq (7a). The four steady-state, hour-long cooling tests, corresponding to a cooling load factor of 1.0 , had an average ordinate of 0.99 , which indicates good agreement between the measured steady-state efficiency of the heat pump and the manufacturer's data. The data points represented by circles correspond to time periods consisting of all the consecutive hours in each 24-hour period for which a cooling load existed. The triangular data points represent time periods which were selected for analysis because the heat pump's COP could be determined for a complete number of ON-OFF cycles and the cooling load was approximately constant. As can be seen from figure 4, data were only obtained for load factors less than 0.35. This was due to unseasonably mild weather which existed during and after the pre-retrofit cooling test. A straight line is shown passing through the data in figure 4, with the region where no data exist being indicated by a broken line. Although the lack of data over the entire load range precludes certainty as to the exact shape of the curve in figure 4 , this straight line approximation is believed to be correct because similar results were obtained during the post-retrofit heating test.

The HEATING COP of the Bowman house heat pump, as calculated using the manufacturer's per-

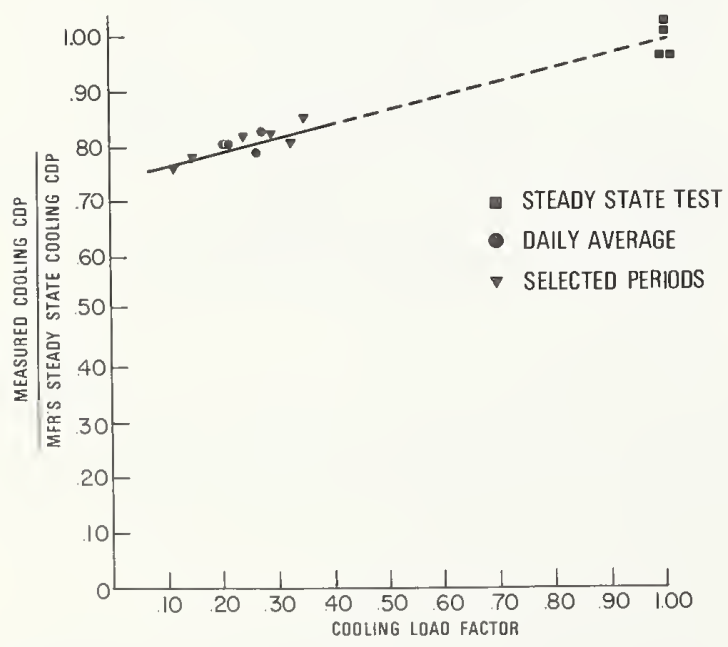

FIGURE 4. Variation in performance with load, cooling operation. formance data, is presented in figure 5 as a function of outdoor temperature for three different return air temperatures. The data presented is for an indoor air flow rate of $1680 \mathrm{CFM}\left(47.58 \mathrm{~m}^{3} / \mathrm{min}\right)$, since this is the average air flow rate existing during the heating test. Correction factors for determining the heating capacity and compressor power consumption at this air flow rate were extrapolated from the manufacturer's data as discussed in the section entitled Experimental Procedures.

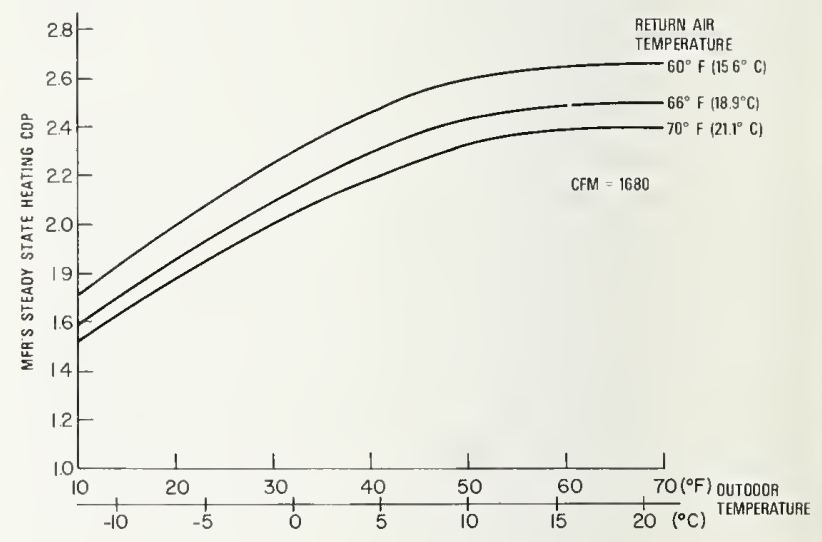

Figure 5. COP calculated from MFR's data, heating operation.

Figure 6 is a plot giving the heat pump's capacity (as obtained from the manufacturer's performance data) at various outdoor temperatures and three different curves showing heating load versus outdoor temperature. The heating capacity is for a return air temperature of $70^{\circ} \mathrm{F}\left(21^{\circ} \mathrm{C}\right)$ and an indoor air flow rate of $1680 \mathrm{CFM}\left(47.58 \mathrm{~m}^{3} / \mathrm{min}\right)$. Two of the heating load curves were determined for infiltration rates of 1.0 and 0.5 indoor-air changes per hour using ASHRAE procedures [5] for calculating the heating requirement at the outdoor design temperature. The third heating load curve was obtained by passing a least-square-fit straight line through experimental data and an assumed point. The experimental data corresponded to 24-hour averages of the heat delivered to the Bowman house per hour plotted against the average outdoor temperature existing in each 24 -hour period. The data were corrected to an indoor temperature of $70^{\circ} \mathrm{F}$ $\left(21^{\circ} \mathrm{C}\right)$, but were not normalized to any standard wind or solar radiation conditions. This lack of normatizing wind and solar effects could be the reason why the heating requirement of the Bowman house with and without storm windows appears to be the same for the data plotted in figure 6 . The assumed point in figure 6 corresponds to a zero heating requirement at an outdoor temperature of $67.5^{\circ} \mathrm{F}\left(19.7^{\circ} \mathrm{C}\right)$, and $w$ as arrived at by calculating the outdoor temperature at which the heat generated by the operating interior lights would just 


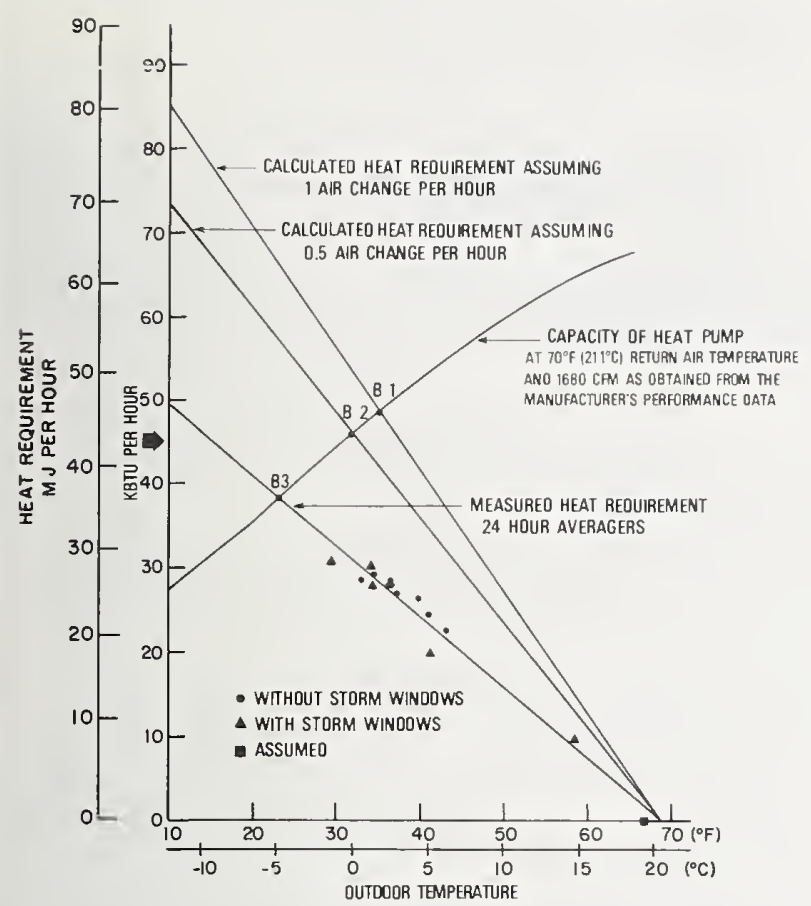

FiguRE 6. Heat requirement of house versus outdoor temperature, indoor temperature $=70^{\circ} \mathrm{F}\left(21.1^{\circ} \mathrm{C}\right)$.

cancel the heat loss from the house. Although it was originally felt that the infiltration rate would be at least one air change per hour, actual measurement using a tracer gas [2] showed it to be around 0.5 air changes per hour. Even at the correct infiltration rate, however, the ASHRAE procedure for determining the heating load at the outdoor design temperature considerably overestimated the heating requirement of the Bowman house. This is probably due to the fact that the ASHRAE method is for design conditions with a $15 \mathrm{mph}$ wind and does not include the effect of sunshine in reducing the heating load. The points $B_{1}, B_{2}$, and $B_{3}$, which are referred to as "balance points," give the respective outdoor temperatures at which the heat pump's output (without supplemental resistance heaters) would just equal the heating requirement if the heating load curve passing through each point represented the heating requirements of the Bowman house. Although it appears from the experimental data that $\mathrm{B}_{3}$ (about $23^{\circ} \mathrm{F}\left(5^{\circ} \mathrm{C}\right)$ ) should be the correct balance point, the actual balance point turned out to be in the neighborhood of $30^{\circ} \mathrm{F}$ $\left(-1.1^{\circ} \mathrm{C}\right)$ which is closer to $\mathrm{B}_{2}$. This was due to the fact that the heating capacity of the heat pump in this temperature region was considerably reduced from the value given by the manufacturer due to frost buildup on the outdoor coil and the need for repeated defrost.

The heating load factor, as defined by eq (7b), may be estimated from figure 6 by dividing the measured heating requirement at a given tempera- ture by the manufacturer's steady-state capacity at the same temperature. This has been done in figur: 7 , where the resulting curve should be considered as providing only an approximate relationship between heating load factor and outdoor temperature. since the heating requirement of a hrouse is also a function of the amount of solar radiation received. wind speed, and the thermal storage capacity of the structure. These variables could cause the hrouse's daily heating requirement for particular days (o) deviate from the straight line passing through $B_{3}$ in figure 6 . In addition, considerable deviation can be expected from this line for the heating reguirement during periods of time less than 24 hours. It should be pointed out that since the definition of heating load factor involves the manufacturer's steady-state capacity, which might be considered an ideal capacity, the heat punp's balance point was actually located somewhere between a load factor of 0.70 and 0.80 . Thus the heat pump operated continuously at a heating load factor considerably less than 1.00 .

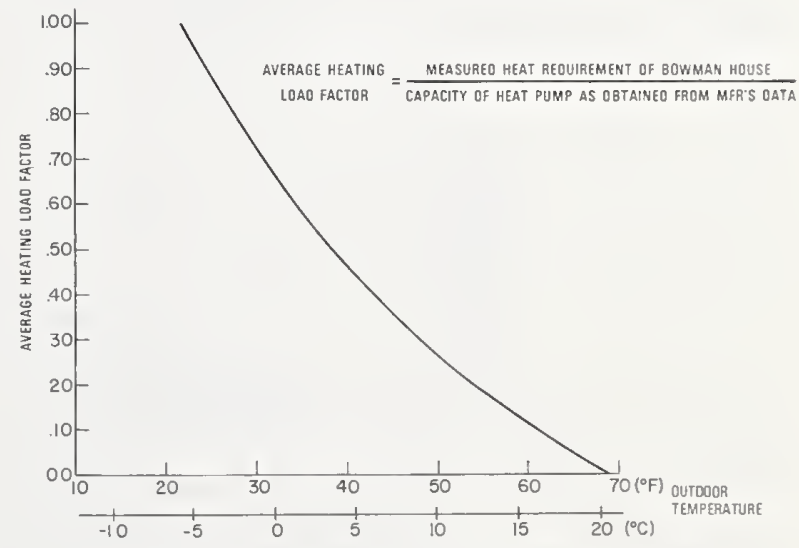

Figure 7. Average Heating versus outdoor temperature.

Figure 8 shows the effect of cycling on the heating performance of the Bowman house heat pump. The data plotted in this figure are of two kinds. For outdoor temperatures above $40^{\circ} \mathrm{F}(4.4$ $\left.{ }^{\circ} \mathrm{C}\right)$, cycles were selected which appeared to be representative of the heat pump's performance at various temperatures. The heating COP. heating load factor, and manufacturer"s steady-state COP (as calculated from the manufacturer's performance data) were determined for each cycle and plotted as shown. For outdoor temperatures below $40^{\circ} \mathrm{F}$ $\left(4.4{ }^{\circ} \mathrm{C}\right)$, the first cycle occurring after a cycle involving a defrost period was selected, analyzed and plotted. Thus the data shown in figure 8 , do not show the effect of frost buildup and defrosting on the performance of the heat pump. Since frost buildup does occur and defrosting is necessary. figure 8 cannot be used for predicting the perfor- 


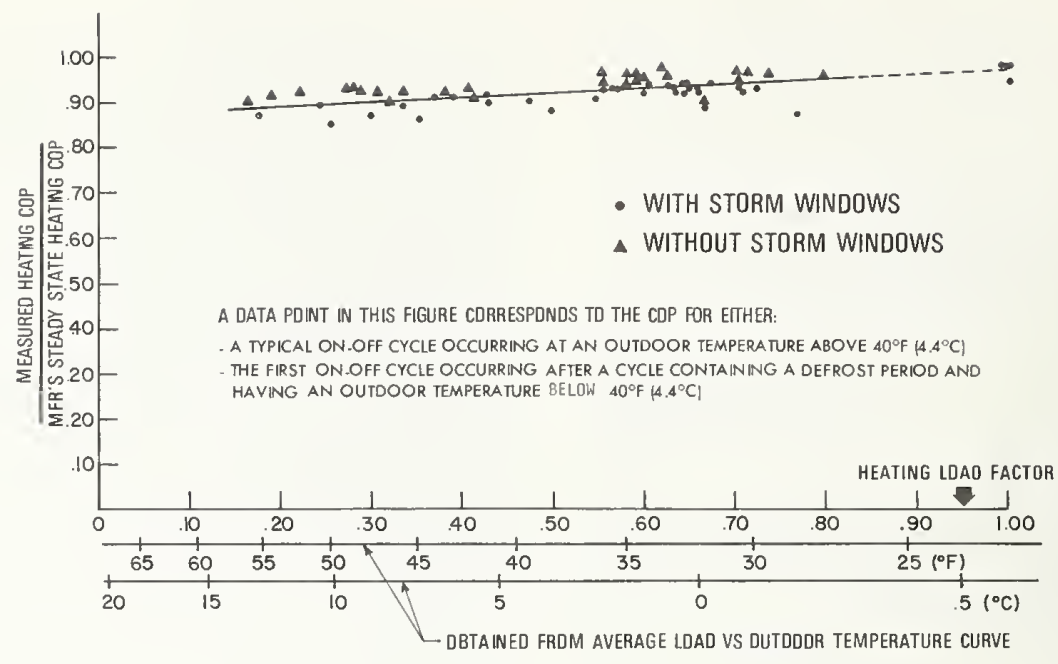

FIGURE 8. Effect of cycling on heat pump performance, heating operation.

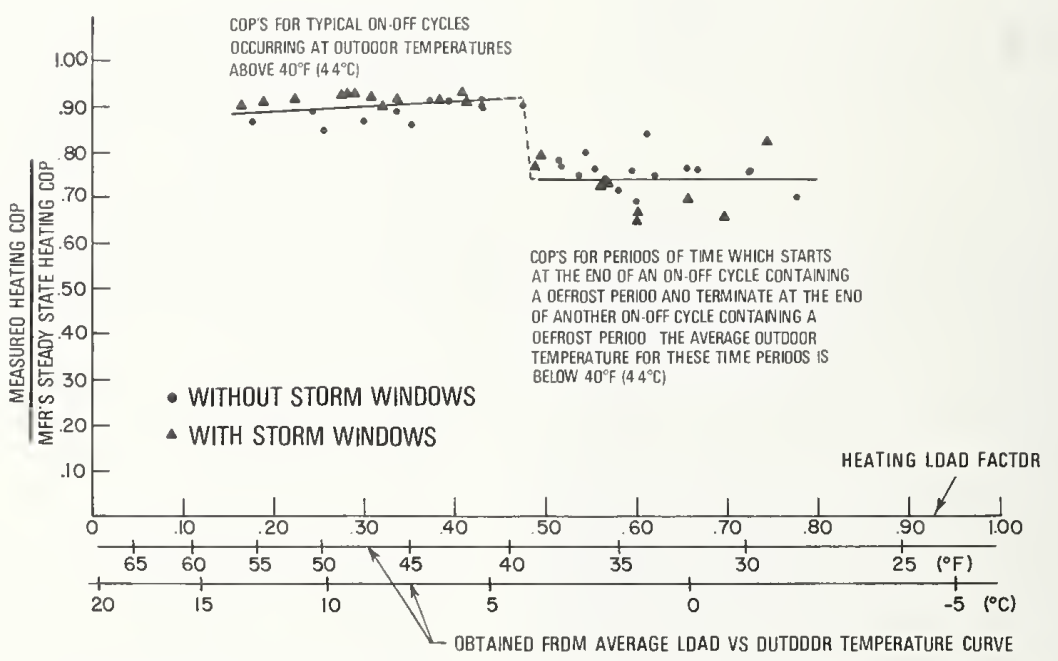

FIGURE 9. Variation in heat pump performance with load, heating operation.

mance of the Bowman house heat pump in the defrost region. It does, however, indicate that the linear approximation used in analyzing the cooling data in figure 4 is probably correct.

Figure 9 shows the heating performance of the Bowman house heat pump as a function of the heating load factor. For outdoor temperature above $40{ }^{\circ} \mathrm{F}\left(4.4{ }^{\circ} \mathrm{C}\right)$ the data shown in figure 8 , are replotted here. For temperatures below $40^{\circ} \mathrm{F}$ $\left(4.4^{\circ} \mathrm{C}\right)$, the heating COP, heating load factor, and manufacturer's steady-state COP were determined for periods of time which started at the end of an ON-OFF cycle containing a defrosting process and terminated at the end of another ON-OFF cycle containing a defrosting process. The minimum period of time analyzed was 3 hours, while the maximum was almost 24 hours. These time periods always contained many ON-OFF cycles and a number of periods contained multiple defrosting processes. Since considerable scatter existed in the data obtained for temperatures below $40^{\circ} \mathrm{F}\left(4.4^{\circ} \mathrm{C}\right)$, the ordinates of all the data points were averaged and found to have a value of 0.74 . A straight line parallel to the $\mathrm{X}$ axis was then passed through these data in figure 9 at this average height.

In order to determine if the solid lines drawn through the data in figure 9 were truly representive of the Bowman house heat pump's performance, all the heat pump data collected after the first and second stages of retrofit were used to determine an average hourly heating COP for the post-retrofit heating test. The result was: 
(Average Hourly Heating COP) $\equiv$

$$
\equiv \frac{1}{N} \sum_{i=1}^{N}(\mathrm{COP})_{i}=1.71
$$

where $(\mathrm{COP})_{i}=\mathrm{COP}$ measured for hour $i$ and $N$ $=$ the total number of hours of data $=373$.

The average hourly COP was then calculated for the same period by determining the manufacturer's steady-state COP for each hour, multiplying by a correction factor obtained from figure 9 and then averaging. It was found that:

$$
\begin{gathered}
\text { (Average Hourly Heating COP) } \begin{array}{c}
\text { (catculated } \\
\text { using figure } 9
\end{array} \\
\text { ust }
\end{gathered}
$$

$\equiv \frac{1}{N} \sum_{j=1}^{N}(\text { Mfr's steady-state heating COP })_{j}$

$$
\times\left(\text { Correction factor }\left(T_{j}\right)\right)_{j}=1.76
$$

where the MFG's steady-state heating COP is the heating COP obtained from the manufacturer performance data for hour $j$ and the correction factor is the ordinate of the curve in figure 9 corresponding to average outdoor temperature, $T_{j}$, for hour $j$. The measured and calculated average hourly heating COP's were found to agree within 3 percent.

The seasonal performance factor (SPF) of the Bowman house heat pump was estimated using the bin method and weather data for Andrews Air Force Base, which is near Washington, D.C. The equation used was:

Total Energy Delivered Over The Heating

$$
\begin{aligned}
& \mathrm{SPF}=\frac{\text { Total Energy Input Over the Heating }}{\text { Season }} \\
& \simeq \frac{\sum_{j=1}^{M} 0_{j}^{\mathrm{HP}}+\sum_{j=1}^{M} 0_{j}^{s}}{\sum_{j=1}^{M} I_{j}^{\mathrm{HP}}+\sum_{j=1}^{M} I_{j}^{s}}=\frac{\sum_{j=1}^{M} 0_{j}^{\mathrm{HP}}+\sum_{j=1}^{M} 0_{j}^{s}}{\sum_{j=1}^{M} \frac{0_{j}^{\mathrm{HP}}}{(\mathrm{COP})_{j}}+\sum_{j=1}^{M} 0_{j}^{S}}
\end{aligned}
$$

where

$j$

$M \quad$ is the total number of temperature bins used

$0_{j}^{\mathrm{HP}} \quad$ is the heat supplied in temperature bin $j$ by the heat pump over the entire heating season is the heat supplied in temperature bin $j$ by the supplemental resistance heaters over the entire heating season

$\gamma_{j}^{H P} \quad$ is the energy used by the heat pump in delivering heat $0_{j}^{\mathrm{HP}}$ and is equal $100_{j}^{\mathrm{HP}} /$ $(\mathrm{COP})_{j}$

$(\mathrm{COP})_{j} \quad$ is the average seasonal HEATING $\mathrm{COl}^{\prime}$ of the heat pump for temperature bin $j$

$I_{j}^{s}$

is the energy required by the supplemental resistance heaters to produce heat $0_{j}^{s}$ and is equal to $0_{j}^{\xi}$, assuming jacket losses are negligible.

Two calculations were performed to determine the expected SPF of the Bowman house heat pump. The first one approximated $(\mathrm{COP})_{j}$ by the steady-state heating COP, which was calculated from the manufacturer's performance data for temperature bin $j$. The second calculation took

$(\mathrm{COP})_{j}=$ (Manufacturer's steady state HEATING COP for temperature bin $j$ ) (correction factor obtained from figurc 9 for temperature $\operatorname{bin} j$ ).

These calculations are shown in table 1. Using the manufacturer's steady-state data, the SPF was predicted to be 2.16. Employing the results in figure 9 to correct for the effect of cycling, frost buildup and defrost, the SPF of the Bowman house heat pump turned out to be 1.74 or some 19 percent lower.

The procedure used in table 1 to estimate the SPF of the Bowman house heat pump yields the same result as the method recommended by the manufacturer of the heat pump for the case where $(\mathrm{COP})_{j}$ is calculated from the manufacturer's performance data. It is interesting to note, however, that this method indicates that the Bowman house heat pump supplied 98 percent of the total energy required over the heating season, and the supplemental heaters supplied only 2 percent. This is really an underestimation of the supplemental heat required because the method assumes that the capacity of the heat pump in the defrost region is the same as that given in the steady-state performance data. This assumption results in a balance point at B3 as shown in figure 6 . As pointed out earlier, this is not the case, since the capacity of the heat pump in the defrost region is affected adversely by frost buildup and defrosting and this results in the actual balance point being closer to B2. Thus more supplemental resistance heat is required than accounted for in table 1 , and the estimated SPF should actually be slightly less than 1.74. The resulting change would, however, be small and for simplicity, this effect is not included in the calculations presented in table 1. 


\section{TABLE 1 ESTIMATED SPF OF BOWMAN HOUSE HEAT PUMP}

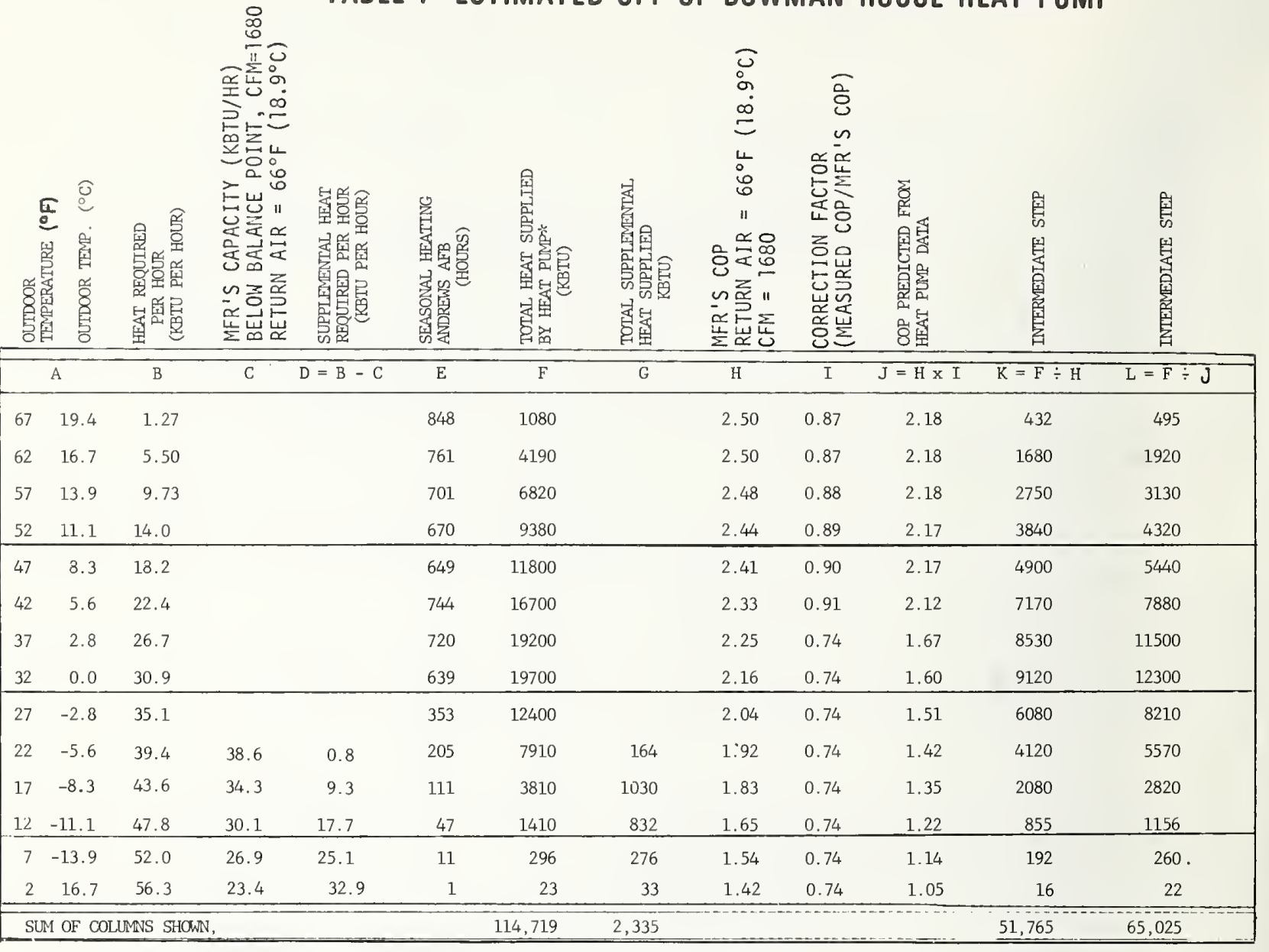

$* F=\left\{\begin{array}{l}B \times E \text { above balance pt. } \\ C \times E \text { below balance pt. }\end{array}\right.$

SPF Predicted Using $=\frac{\varepsilon_{F}+\varepsilon_{G}}{\varepsilon_{K}+\varepsilon_{G}}=\frac{114,719+2,335}{51,765+2,335}=2.16$
MFR'S Data

$* * E_{\mathrm{x}}=$ Sum of Colum $\mathrm{X}$

SPF Predicted Using
Results in Figure 9

Table 1

\section{Comparison with Present Day Fossil-Fuel Heating Equipment}

In order to compare the energy effectiveness of the Bowman house heat pump with fossil-fuel heating equipment, it is necessary to trace the energy consumption of the heat pump back to the primary source energy used by the power plant. This may be done by defining an EFFECTIVE HEATING COP which is given by:

EFFECTIVE HEATING COP

$$
=(0.29) \text { (heat pump's HEATING COP) }
$$

where 0.29 takes into account the fact that, on the average, only about 29 percent of the heat energy of the fuel burned at the power plant in making electricity will reach the heat pump [6]. Table 2 lists the EFFECTIVE HEATING COP of the Bowman house heat pump at various outdoor temperatures, assuming that the heat pump"s heating COP may be obtained by correcting the manufacturer's steady-state COP using the results presented in figure 9. Equation (11) may also be used to determine an EFFECTIVE SPF, where

EFFECTIVE SPF $=(0.29)(1.74)=0.50$. 
TABLE 2 efFective heAtING COP for Bowman House Heat Pump

\begin{tabular}{|c|c|c|c|c|c|c|c|}
\hline OUTOOOR TEMPERATURE & $2^{\circ} \mathrm{F}$ & $12^{\circ} \mathrm{F}$ & $22^{\circ} \mathrm{F}$ & $32^{\circ} \mathrm{F}$ & $42^{\circ} \mathrm{F}$ & $52^{\circ} \mathrm{F}$ & $62^{\circ} \mathrm{F}$ \\
\cline { 2 - 8 } & $-16.7^{\circ} \mathrm{C}$ & $-11.1^{\circ} \mathrm{C}$ & $-5.6^{\circ} \mathrm{C}$ & $0^{\circ} \mathrm{C}$ & $5.6^{\circ} \mathrm{C}$ & $11.1^{\circ} \mathrm{C}$ & $16.7^{\circ} \mathrm{C}$ \\
\hline $\begin{array}{c}\text { COP CALCULATED } \\
\text { FROM MFR'S OATA }\end{array}$ & 1.42 & 1.65 & 1.92 & 2.16 & 2.33 & 2.44 & 2.50 \\
\hline $\begin{array}{c}\text { COP PREOICTEO } \\
\text { USING RESUITS PRESENTED } \\
\text { IN FGURE } 9\end{array}$ & 1.05 & 1.22 & 1.42 & 1.60 & 2.12 & 2.17 & 2.18 \\
\hline $\begin{array}{c}\text { EFFECTIVE COP }=(0.29) \\
\text { (COP Predicted USING RESUTS } \\
\text { PRESENTEO IN FGURE 9) }\end{array}$ & 0.30 & 0.35 & 0.41 & 0.46 & 0.61 & 0.63 & 0.63 \\
\hline
\end{tabular}

Results presented are for a CFM of 1680 and a return air temperature of $66^{\circ} \mathrm{F}\left(18.9^{\circ} \mathrm{C}\right)$

Table 2

Thus for every unit of energy consumed at the power plant, only about 0.5 units of heat were delivered, on the average, to the interior living space of the Bowman house. Even if this value of the EFFECTIVE SPF were to be corrected to the manufacturer's recommended indoor air flow, the effect would only be to increase it by approximately 6 percent to a value of 0.53 .

If an attempt is made to compare this estimated seasonal performance of the Bowman house heat pump with that of fossil-fuel equipment, it is found that considerable controversy exists concerning the seasonal efficiency of residential gas and oil-fired heating systems. Numerous studies exist which report seasonal efficiencies from 3.5 percent to 65 percent for this type of equipment [6]. Many of these studies, however, involved the comparison of houses equipped with fossil-fuel heating equipment with those using electric resistance heating and often considerable differences existed between the two types of houses in the amount of installed insulation, tightness with respect to air infiltration, and occupant usage. Many other studies calculated the heating requirements of the house at various outdoor temperatures, neglecting the heat contributed by lighting, appliances, occupants and solar, and used monthly fuel bills to determine seasonal efficiencies. These procedures usually underestimated or overestimated the seasonal efficiency of residential fossil-fuel heating equipment and have contributed greatly to the controversy.

Recently, another approach to determining the seasonal performance of fossil-fuel heating equipment has been undertaken by the Honeywell Corporate Research Center with their development of a computer model for such equipment. The model is capable of calculating the seasonal losses, including those due to the presence of $\mathrm{H}_{2}$ in the fuel; the heat contained in the products of combustion and excess air going up the flue, and off-cycle drafts passing through the heat exchanger. Figure 10 summarizes the results obtained when this model was used to calculate the seasonal efficiency of a typical gas-fired furnace operating in Minnesota [7]. A seasonal efficiency of 57.1 percent was obtained. with off-cycle losses constituting the largest single loss of 12.7 percent. Honeywell is presently in the process of verifying this model by comparing its

\section{CALCULATED SEASONAL LOSSES}

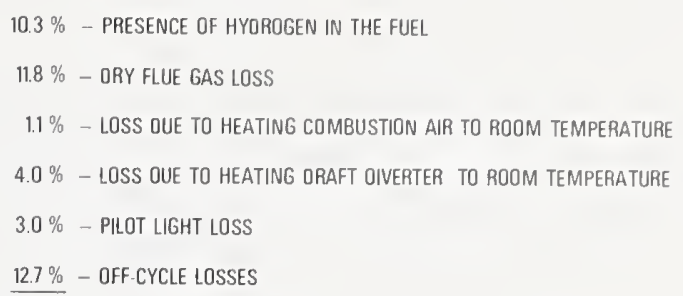

$42.9 \%$ - TOTAL SEASONAL LOSS

CALCULATED SEASONAL EFFICIENCY $=57.1 \%$

FiguRE 10. Typical seasonal performance of a gas-fired furnuse [7].

output with results obtained from experiments (*m1ducted in the laboratory and field. Once this process is completed, such a model could be a powerful tool for determining the average statsonal efficiency of different types of fossil-fuch hrating equipment.

Recognizing the probtems invotved with all the studies which have been conducted on the seasmal efficiency of fossil-fuel residential heating equipment, it seems safest to conchude that: (a) there is likely a wide spread in seasonal efficiencies even among the same types of heating equipment and (b) there probably exists a large number of gas and oilfired residential furnaces and boilers which have seasonal efficiencies in the 50 to 60 percent range. Assuming this to be true, the estimated seasunal performance of the heat pump used in this stud! was equivalent to the performance of many rosidential gas- and oil-fired heating systems.

\section{Discussion}

The effect of part-load operation on the performance of the Bowman house heat pump was found to be greatest when the heat pump operated in the cooling mode. At a cooling load factor of 0.30 . the ratio of the heat pump's COOLING COP to the manufacturer's steady-state COOLING COP was reduced to approximately 82 percent of the measured steady-state value (see fig. 4); at a heating load factor of 0.30 , the ratio of the HEATING COP to the manufacturer's steady-state HEATING COP was roughly 94 percent of the measured steadystate value (see fig. 9). A large part of the difference in cooling and heating performance at part load was due to the fact that the heat pump was located in the basement and, in the heating mode, the heat contained in the indoor unit would tend to be transferred to the interior living space by natural convection during the OFF cycles. In the cooling mode, however, the coolness was trapped in the indoor unit during OFF-cycles and most of it was eventually transferred to the basement. The 
situation might have been reversed, with the HEATING COP being more affected by part-load operation, if the indoor unit had been located in the attic.

ln the heating mode of operation, the largest adverse effect on the performance of the Bowman house heat pump was due to frost buildup on the outdoor coil and the resulting requirement for defrosting this coil. For outdoor temperatures below $40^{\circ} \mathrm{F}\left(4.4^{\circ} \mathrm{C}\right)$, the average ratio of HEATING COP to manufacturer's steady-state HEATING COP in figure 9 was 77 percent of the measured steadystate value in figure 8 which does not contain the effect of frost buildup or defrosting. This result would tend to indicate the need for research to develop improved defrosting methods and to determine the effect of different coil designs upon heat pumps performance in the high frost region.

The seasonal performance factor or SPF of the Bowman house heat pump was estimated to be 1.74 using the results presented in figure 9 and weather data which were representative of the Washington, D.C. area. This turned out to be approximately 19 percent lower than the SPF calculated using the manufacturer's performance data. This difference in seasonal performance was due to the effect of part-load operation, frost buildup and defrosting.

When the estimated seasonal heating performance of the Bowman house heat pump was traced back to the power plant, it was found that only about a half - unit of heat energy was actually delivered to the interior living space for every unit of energy consumed at the power plant. This is comparable to the probable performance of many gas- and oil-fired residential heating units. If this estimated seasonal performance of the Bowman house heat pump is representative of residential heat pumps in areas having heating seasons similar to Washington, D.C., there does not appear to be any clear-cut advantage to choosing either a heat pump or a fossil-fuel heating system in these areas for the purpose of saving primary source energy.

\section{References}

[1] Newman, Dorothy K. and Day, Dawn, The American Energy Consumer (Ballinger Publishing Co., Cambridge, 1975).

[2] Burch, D. et.al., Experimental Study of Retrofitting Existing Residences, (to be published).

[3] ASHRAE Handbook of Fundamentals, 1973 (ASHRAE, N.Y., 1972), Page 440.

[4] Method of Testing for Rating Unitary Air Conditioning and Heat Pump Equipment, ASHRAE Standard 37-69, (American Society of Heating, Refrigeration and Air-Conditioning Engineers, New York, 1969).

[5] ASHRAE Handbook of Fundamentals, Chapter 21, 1973 (American Society of Heating, Refrigeration and AirConditioning Engineers, New York 1972).

[6] Hise, E.C., Seasonal Fuel Utilization Efficiencies of Residential Heating Systems, Oak Ridge National Laboratory Report ORNL-NSF-EP-82.

[7] Bonne, U., and Johnson, A.E., Thermal Efficiency In NonModulating Combustion Systems, Proceedings and Addendum to the Proceedings of the Conference on Improved Efficiency in HVAC Equipment and Components for Residential and Small Commercial Buildings, Purdue University, October 7-8, 1974. 
NBS-114A (REV. 7-73)

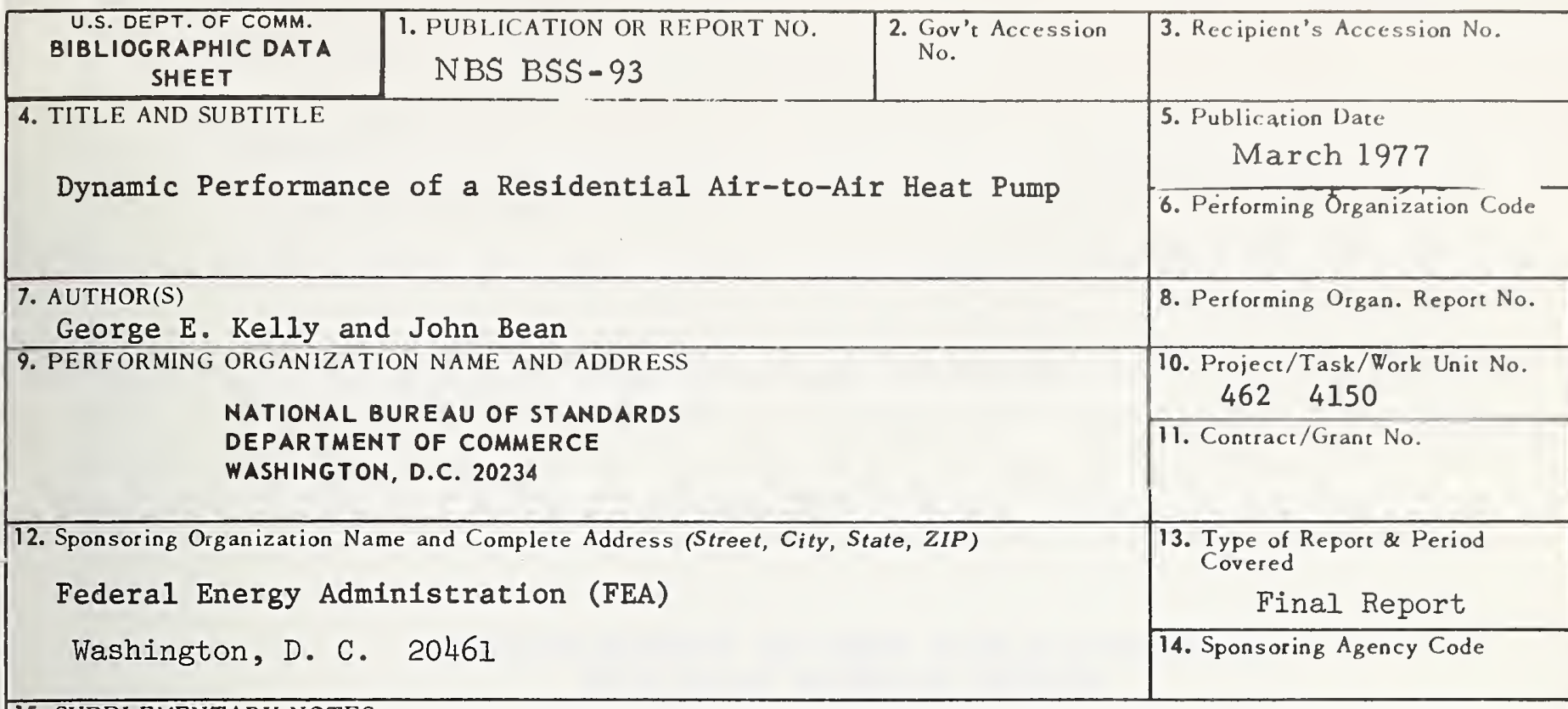

15. SUPPLEMENTARY NOTES

Library of Congress Catalog Card Number: 76-50050

16. ABSTRACT (A 200-word or less factual summary of most significant information. If document includes a significant bibliography or literature survey, mention it here.)

Information is presented on the dynamic performance of a 5-ton air-to-air heat pump, which was installed in a residence in the Washington, D.C. area. The effect of part-load operation on the heat pump's COOLING and HEATING coefficients of performance (COP) was determined. When the pump operated in the heating mode at outdoor temperatures below $40^{\circ} \mathrm{F}\left(4.4^{\circ} \mathrm{C}\right)$, a considerable discrepancy was found to exist between the measured performance and the performance data supplied by the manufacturers. This discrepancy is apparently due to the adverse effects of frost buildup and defrosting of the outdoor coil. The seasonal performance factor (SPF) of the heat pump was estimated and then traced back to the power plant to obtain an "EFFECTIVE SPF" which is then compared with the performance which might be expected from fossil-fuel heating equipment.

17. KEY WORDS (six to twelve entries; alphabetical order; capitalize only the first letter of the first key word unless a proper name; separated by semicolons)

Cooling and Heating Coefficients of Performance; Effective Seasonal Heating COP; Heat Pumps; Heat Pumps and Energy Conservation; Part-Load Performance; Seasonal Performance Factor.
18. AVAILABILITY
X Unlimited

For Official Distribution. Do Not Release to NTIS

X] Order From Sup. of Doc., U.S. Government Pfigting Office Washington, D.C. 20402, SD Cat. No. C13.29/2:93

$[$ Order From National Technical Information Service (NTIS) Springfield, Virginia 22151

\begin{tabular}{|l|c|}
\hline $\begin{array}{l}\text { 19. SECURITY CLASS } \\
\text { (THIS REPURT) }\end{array}$ & 21. NO. OF P AGES \\
UNCL ASSIFIED & 18 \\
\hline $\begin{array}{l}\text { 20. SECURITY CLASS } \\
\text { (THIS PAGE) } \\
\text { UNCLASSIFIED }\end{array}$ & $\begin{array}{l}\text { 22. Price } \\
45 \text { cents }\end{array}$ \\
\hline
\end{tabular}





\section{ANNOUNCEMENT OF NEW PUBLICATIONS IN BUILDING SCIENCE SERIES}

Superintendent of Documents, Government Printing Office,

Washington, D.C., 20402

Dear Sir:

Please add my name to the announcement list of new publications to be issued in the series: National Bureau of Standards Building Science Series.

Name

Company

Address .

City

State

Zip Code

(Notification key N-339) 


\section{PERIODICALS}

JOURNAL OF RESEARCH reports National Bureau of Standards research and development in physics, mathematics, and chemistry. It is published in two sections, available separately:

- Physics and Chemistry (Section A)

Papers of interest primarily to scientists working in these fields. This section covers a broad range of physical and chemical research, with major emphasis on standards of physical measurement, fundamental constants, and properties of matter. Issued six times a year. Annual subscription: Domestic, \$17.00; Foreign, \$21.25.

- Mathematical Sciences (Section B)

Studies and compilations designed mainly for the mathematician and theoretical physicist. Topics in mathematical statistics, theory of experiment design, numerical analysis, theoretical physics and chemistry, logical design and programming of computers and computer systems. Short numerical tables. Issued quarterly. Annual subscription: Domestic, $\$ 9.00$; Foreign, $\$ 11.25$.

DIMENSIONS/NBS (formerly Technical News Rulletin)-This monthly magazine is published to inform scientists, engineers, businessmen, industry, teachers, students, and consumers of the latest advances in science and technology, with primary emphasis on the work at NBS. The magazine highlights and reviews such issues as energy research, fire protection, building technology, metric conversion, pollution abatement, health and safety, and consumer product performance. In addition, it reports the results of Bureau programs in measurement standards and techniques, properties of matter and materials, engineering standards and services, instrumentation, and automatic data processing.

Annual subscription: Domestic, $\$ 9.45$; Foreign, $\$ 11.85$.

\section{NONPERIODICALS}

Monographs-Major contributions to the technical literature on various subjects related to the Bureau's scientific and technical activities.

Handbooks-Recommended codes of engineering and industrial practice (including safety codes) developed in cooperation with interested industries, professional organizations, and regulatory bodies.

Special Publications-Include proceedings of conferences sponsored by NBS, NBS annual reports, and other special publications appropriate to this grouping such as wall charts, pocket cards, and bibliographies.

Applied Mathematics Series-Mathematical tables, manuals, and studies of special interest to physicists, engineers, chemists, biologists, mathematicians, computer programmers, and others engaged in scientific and technical work.

National Standard Reference Data Series-Provides quantitative data on the physical and chemical properties of materials, compiled from the world's literature and critically evaluated. Developed under a world-wide program coordinated by NBS. Program under authority of National Standard Data Act (Public Law 90-396).
NOTE: At present the principal publication outlet for these data is the Journal of Physical and Chemical Reference Data (JPCRD) published quarterly for NBS by the American Chemical Society (ACS) and the American Institute of Physics (AIP). Subscriptions, reprints, and supplements available from. ACS, 1155 Sixteenth St. N.W., Wash. D. C. 20056.

Building Science Series-Disseminates technical information developed at the Bureau on building materials, components, systems, and whole structures. The series presents research results, test methods, and performance criteria related to the structural and environmental functions and the durability and safety characteristics of building elements and systems.

Technical Notes-Studies or reports which are complete in themselves but restrictive in their treatment of a subject. Analogous to monographs but not so comprehensive in scope or definitive in treatment of the subject area. Often serve as a vehicle for final reports of work performed at NBS under the sponsorship of other government agencies.

Voluntary Product Standards-Developed under procedures published by the Department of Commerce in Part 10, Title 15, of the Code of Federal Regulations. The purpose of the standards is to establish nationally recognized requirements for products, and to provide all concerned interests with a basis for common understanding of the characteristics of the products. NBS administers this program as a supplement to the activities of the private sector standardizing organizations.

Consumer Information Series-Practical information, based on NBS research and experience, covering areas of interest to the consumer. Easily understandable language and illustrations provide useful background knowledge for shopping in today's technological marketplace.

Order above NBS publications from: Superintendent of Documents, Government Printing Office, Washington, D.C. 20402 .

Order following NBS publications-NBSIR's and FIPS from the National Technical Information Services, Springfield, Va. 22161.

Federal Information Processing Standards Publications (FIPS PUBS)-Publications in this series collectively constitute the Federal Information Processing Standards Register. Register serves as the official source of information in the Federal Government regarding standards issued by NBS pursuant to the Federal Property and Administrative Services Act of 1949 as amended, Public Law 89-306 (79 Stat. 1127), and as implemented by Executive Order 11717 (38 FR 12315, dated May 11, 1973) and Part 6 of Title 15 CFR (Code of Federal Regulations).

NBS Interagency Reports (NBSIR)-A special series of interim or final reports on work performed by NBS for outside sponsors (both government and non-government). In general, initial distribution is handled by the sponsor; public distribution is by the National Technical Information Services (Springfield, Va. 22161) in paper copy or microfiche form.

\section{BIBLIOGRAPHIC SUBSCRIPTION SERVICES}

The following current-awareness and literature-survey bibliographies are issued periodically by the Bureau:

Cryogenic Data Center Current Awareness Service. A literature survey issued biweekly. Annual subscription: Domestic, $\$ 20.00$; Foreign, $\$ 25.00$.

Liquified Natural Gas. A literature survey issued quarterly. Annual subscription: $\$ 20.00$.
Superconducting Devices and Materials. A literature survey issued quarterly. Annual subscription: $\$ 20.00$. Send subscription orders and remittances for the preceding bibliographic services to National Bureau of Standards, Cryogenic Data Center (275.02) Boulder, Colorado 80302 . 
U.5. DEPARTMENT OF COMMERCE

Mational Bureau of Standerds

Washington, D.C. 20234

DFFICIAL BUSINESS

Penalty for Private Use, $\$ 300$
POSTAGE AND FEES PAID

U.S. DEPARTMENT OF COMMERCE $C O M=215$

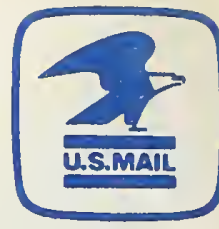

SPECIAL FOURTH-CLASS RATE

BOOK 